International Journal of Automotive and Mechanical Engineering (IJAME)

ISSN: 2229-8649 (Print); ISSN: 2180-1606 (Online); Volume 7, pp. 1014-1022, January-June 2013

(C) Universiti Malaysia Pahang

DOI: http://dx.doi.org/10.15282/ijame.7.2012.17.0082

\title{
ATMOSPHERIC CORROSION OF STRUCTURAL STEELS EXPOSED IN THE 2004 TSUNAMI-AFFECTED AREAS OF ACEH
}

\author{
M. Ridha ${ }^{1 *}$, S. Fonna ${ }^{1}$, S. Huzni ${ }^{1}$, J. Supardi ${ }^{2}$ and A.K. Ariffin ${ }^{3}$ \\ ${ }^{1}$ Department of Mechanical Engineering, Syiah Kuala University \\ Jl. Tgk. Syech Abdul Rauf 7 Banda Aceh, Indonesia \\ Email: ridha@tdmrc.org \\ ${ }^{2}$ Department of Mechanical Engineering, Teuku Umar University \\ Jl. Alue Penyareng, Meurebo Sub District, Meulaboh, West Aceh, Indonesia \\ ${ }^{3}$ Department of Mechanical and Materials Engineering \\ Universiti Kebangsaan Malaysia, Bangi 43600, Selangor DE, Malaysia
}

\begin{abstract}
Aceh province located at the northwestern tip of Sumatra Island in Indonesia has a coastal environment and a coastline of around $1660 \mathrm{~km}$. Banda Aceh, Aceh Besar, and Aceh Barat are among the districts of Aceh Province located on those coastlines. The earthquake and tsunami that struck Aceh in December 2004 caused much of these districts to be submerged by seawater. Thus, the environment of these areas might become more corrosive. This study investigates atmospheric corrosion of structural steels exposed to the environment by the 2004 tsunami. Some typical structural steels, which have five different shapes, were selected for the test. Atmospheric corrosion tests were employed by referring to ASTM G50 standards. Eight locations were selected as the test sites: Peukan Bada, Ulee Lheu, Lingke, Lampulo, Suak Ribee, Suak Pandan, Suak Seuke, and Suak Geudebang. Following a six-month exposure, experimental results show that the atmospheric corrosion rate for Peukan Bada, Ulee Lheu, Lingke, Lampulo, Suak Ribee, Suak Pandan, Suak Seuke, and Suak Geudebang was 0.0435.451 mpy, 0.035-3.804 mpy, 0.058-5.332 mpy, 0.045-9.727 mpy, 0.265-3.957 mpy, 0.073-2.970 mpy, 0.090-4.101 mpy, and 0.380-6.379 mpy, respectively. The results show that the relative corrosion resistances for all structural steels exposed in these areas can be categorized as good to outstanding. Hence, it is safe to utilize the selected structural steels regarding their atmospheric corrosion resistance.
\end{abstract}

Keywords: Atmospheric corrosion; structural steel; corrosion rate; tsunami-affected area.

\section{INTRODUCTION}

Atmospheric corrosion is the degradation of material as the result of its reaction with the terrestrial atmosphere. Atmospheric substances that induce corrosion mainly include pollutants that are the result of fossil fuel combustion, such as sulfur oxides, chloride ions in coastal areas, and water (ASM International, 2003). The effects of atmospheric corrosion are easy to observe in daily life, such as the rusting of structural steels that are exposed to air. Corrosion can lead to costly consequences if left unattended (NACE, 2002), such as the early failure of equipment and infrastructure (Roberge, 2008).

Many parameters influence atmospheric corrosion: relative humidity, temperature, sulfur dioxide content, hydrogen sulfide content, chloride content, amount of rainfall, dust, and even the position of the exposed metal will affect the its 
characteristics of atmospheric corrosion. Geographical location is also a factor (Schweitzer, 2007); hence, the characteristics of atmospheric corrosion will different for each place. The study of atmospheric corrosion for certain locations and metals has been extensively conducted by many researchers. Ma et al. (2010) performed research on atmospheric corrosion of low carbon steel in Wanning city and Shenyang city, China. Fuente et al. (2011) analyzed the long-term atmospheric corrosion of mild steel in the Spanish atmosphere, and Li et al. (2012) studied the atmospheric corrosion of $\mathrm{Mg}$ alloy in Taiyuan, which is an industrial city in China.

Until mid-2012, however, atmospheric corrosion data were not available for Aceh province, Indonesia. The tsunami in 2004 submerged more than half of the coastal areas of the province, including the districts of Banda Aceh, Aceh Besar, and Aceh Barat. In addition, more than $30 \%$ of the forest along the coastline of the province was destroyed (Kuru, 2005). Because of this, the environment of the tsunami-affected area becomes more corrosive (Ridha et al., 2013); the chloride content and temperature of the local atmosphere become higher, which could bring higher risk of corrosion for exposed structural steel.

In order to understand the impact on the region of the 2004 Sumatra tsunami, it is important to conduct atmospheric corrosion measurements for those metals that are in wide use in the region. During the rehabilitation and reconstruction, some structural steels have been used extensively as materials for infrastructure projects, such as bridges, pipelines, and towers. The purpose of this research is to assess atmospheric corrosion of some structural steels exposed in the 2004 tsunami-affected areas of Aceh province.

\section{EXPERIMENTAL SETUP}

The exposure test was carried out according to ASTM G50 standards. Eight locations were selected: Peukan Bada in Aceh Besar; Ulee Lheu, Lingke, and Lampulo in Banda Aceh; and Suak Ribee, Suak Pandan, Suak Seuke, and Suak Geudebang in Aceh Barat, as shown in Figure 1.

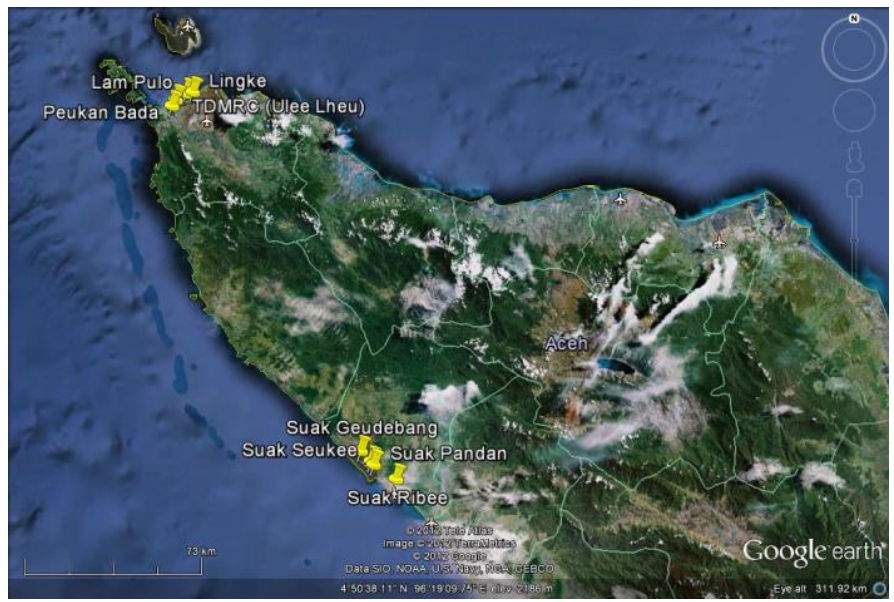

Figure 1. Map of the exposure locations (Google Earth ${ }^{\mathrm{TM}}$ ).

Five different shapes of structural carbon steel were chosen as the specimens for this research: reinforcing steel, bar, L-shaped, plate, and sheet, as shown in Figure 2. 
The dimensions of the specimens are shown in Table 1. As corrosion is a process that occurs on the surface, the different shapes might reveal differing corrosion rates.

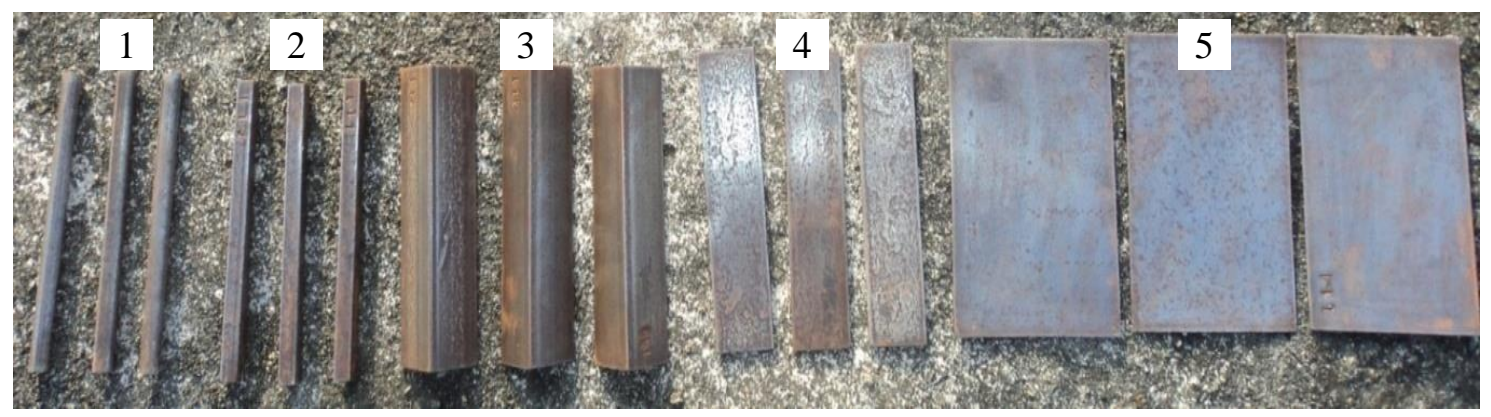

Figure 2. Five forms of the specimens, from left to right: (1) reinforcing steel, (2) bar, (3) L-shaped, (4) plate, (5) sheet.

Table 1. Dimensions of the specimens.

\begin{tabular}{lccccc}
\hline Specimens & $\begin{array}{c}\text { Length } \\
(\mathrm{mm})\end{array}$ & $\begin{array}{c}\text { Wide } \\
(\mathrm{mm})\end{array}$ & $\begin{array}{c}\text { Thickness } \\
(\mathrm{mm})\end{array}$ & $\begin{array}{c}\text { Diameter } \\
(\mathrm{mm})\end{array}$ & $\begin{array}{c}\text { Specimen } \\
\text { quantity }\end{array}$ \\
\hline Reinforcing & 150 & - & - & 12 & 24 \\
Steel & & & & & \\
Bar & 150 & 36 & 3 & - & 24 \\
L-shaped & 150 & 32 & 2 & - & 24 \\
Plate & 150 & 11 & 11 & - & 24 \\
Sheet & 150 & 100 & 1 & - & 24 \\
\hline
\end{tabular}

To perform the exposure, steel racks were used, as shown in Figure 3. The specification of the racks is in accordance with ASTM G50 standards. Plastic holders are used to prevent contact between the specimens and the steel rack.
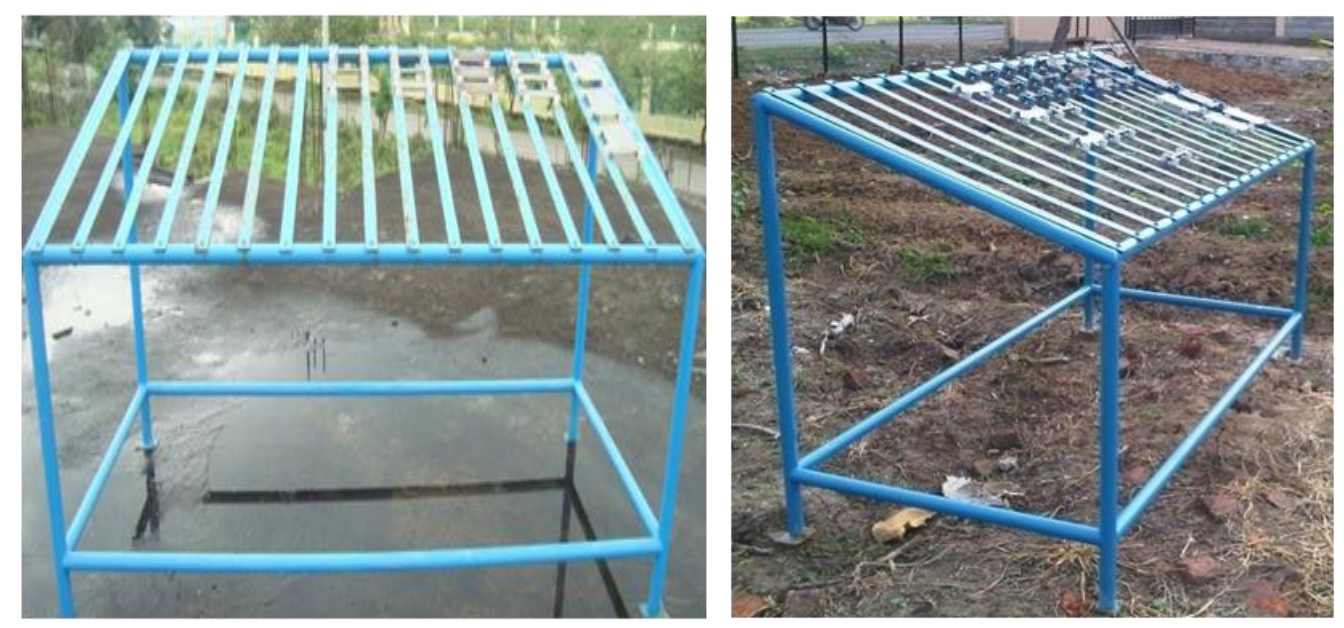

Figure 3. Specimens under exposure mounted on the rack. 
The experiment was conducted for a period of six months from March to August 2012. Each month, the specimens were taken from the exposure site, subjected to cleaning in order to remove corrosion products and then measured to determine the weight loss by using high precision 0.001 gram digital scales, as illustrated in Figure 4.

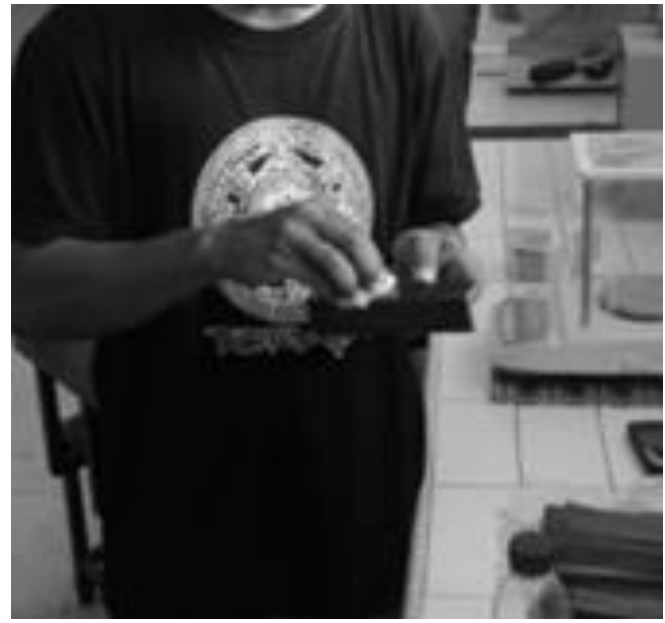

(a)

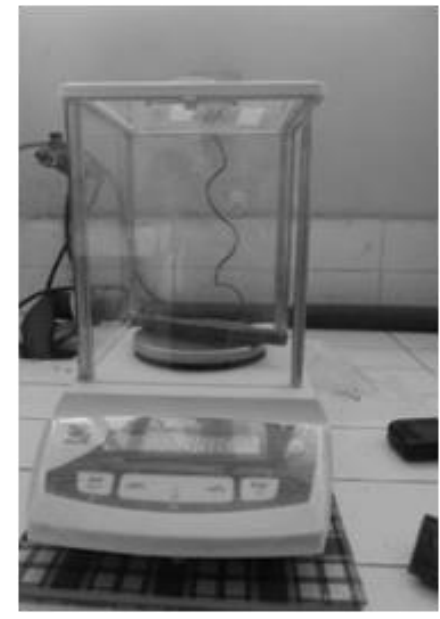

(b)

Figure 4. (a) Cleaning of specimens after exposure, (b) High precision digital scales.

The rate of corrosion of the metals is calculated by using Eq. (1):

$$
C R=\frac{K \times W}{D \times A \times T}
$$

where $C R$ is the corrosion rate (mpy), $K$ is a constant $\left(3.45 \times 10^{6}\right), W$ is weight loss (gram), $A$ is the surface area of the specimen $\left(\mathrm{cm}^{3}\right), T$ is exposure time (hours), and $D$ is the density of the metal $\left(\mathrm{gram} / \mathrm{cm}^{3}\right)$.

The relative corrosion resistances of the structural steels are determined by using the criteria presented in Table 2, which are applicable for typical ferrous-based alloys.

Table 2. Relative corrosion resistance criteria for ferrous-based alloys (Fontana, 1987).

\begin{tabular}{lccccc}
\hline \multirow{2}{*}{$\begin{array}{l}\text { Relative corrosion } \\
\text { resistance }\end{array}$} & \multirow{2}{*}{$\mathrm{mpy}$} & $\mathrm{mm} / \mathrm{yr}$ & $\mu \mathrm{m} / \mathrm{yr}$ & $\mathrm{nm} / \mathrm{hr}$ & $\mathrm{pm} / \mathrm{sec}$ \\
\cline { 3 - 6 } & & $<0.02$ & $<25$ & $<2$ & $<1$ \\
Outstanding mpy & $1-5$ & $0.02-0.1$ & $25-100$ & $2-10$ & $1-5$ \\
Excellence & $5-20$ & $0.1-0.5$ & $100-500$ & $10-50$ & $5-20$ \\
Good & $20-50$ & $0.5-1$ & $500-1000$ & $50-150$ & $20-50$ \\
Fair & $50-200$ & $1-5$ & $1000-5000$ & $150-$ & $50-$ \\
Poor & & & & 500 & 200 \\
& $200+$ & $5+$ & $5000+$ & $500+$ & $200+$ \\
Unacceptable & & & & & \\
\hline
\end{tabular}




\section{RESULTS AND DISCUSSION}

Figure 5 shows the atmospheric corrosion rate of structural steels exposed in Peukan Bada and Ulee Lheu. The figure shows that the corrosion rate ranged from 0.043 to 5.451 mpy and from 0.035 to 3.804 mpy for Peukan Bada and Ulee Lheu, respectively. It can be seen that the corrosion rate of each shape of structural steel varies every month. The maximum corrosion rate occurs during March to May. This might occur because of the high relative humidity and rainfall during those months (BMKG, 2013). Meanwhile, in June to August, the corrosion rate for all specimens is very low; less than $1 \mathrm{mpy}$. Figure 6 shows the corrosion rate of structural steels in Lingke and Lampulo. The corrosion rate for Lingke ranges from 0.058 to $5.332 \mathrm{mpy}$ and for Lampulo the range is 0.045 to $9.727 \mathrm{mpy}$. The figure shows the variation of corrosion rate from March to August for all structural steels. The highest corrosion rate also occurs during March to May, which can be related to the high relative humidity and rainfall in these months (BMKG, 2013). Additionally, from Figures 5 and 6, it can be seen that the form of the structural steels affects the corrosion rate. The structural steel in the form of a bar and reinforcing steel generally have the highest corrosion rate. This is possible linked to different manufacturing and treatment processes experienced by each of the structural steels.

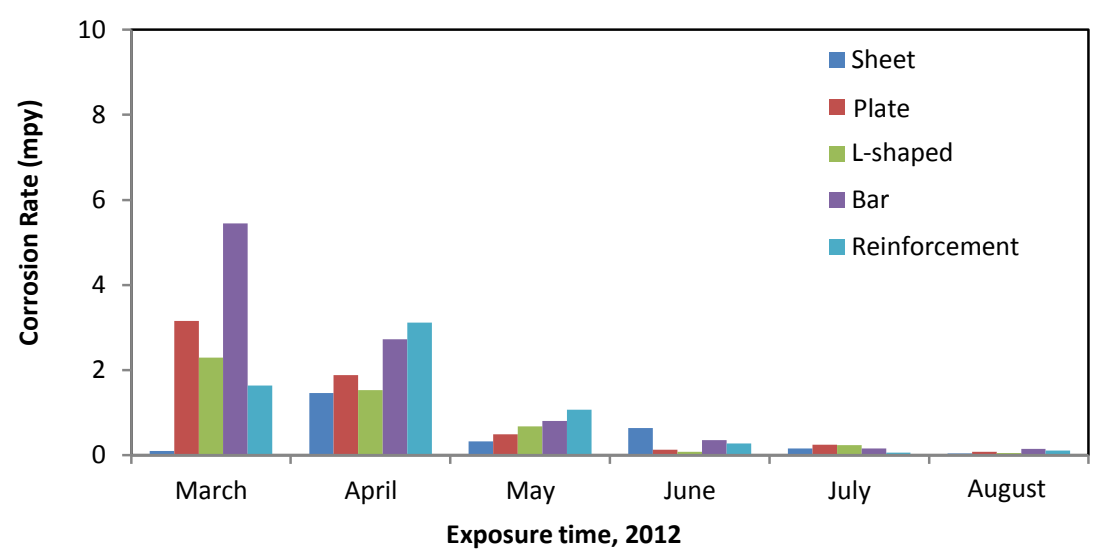

(a)

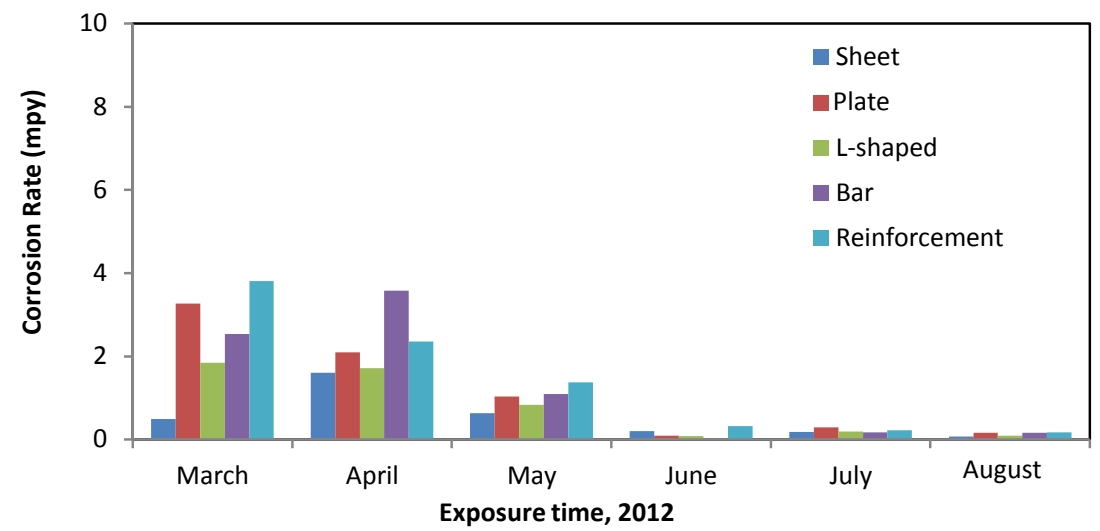

(b)

Figure 5. Corrosion rate from March to August 2012 at: (a) Peukan Bada; (b) Ulee Lheu (TDMRC Ground Zero Building). 


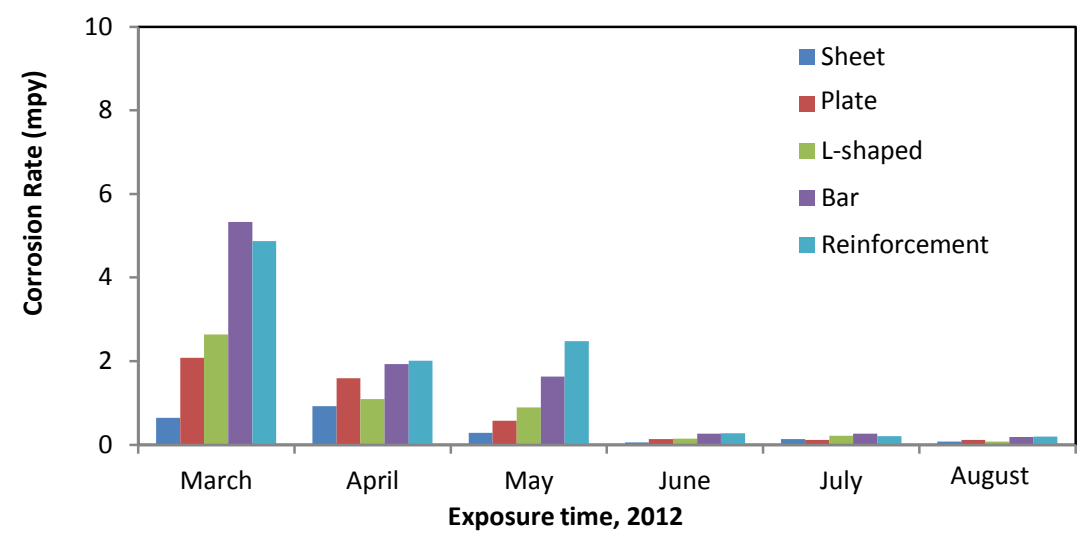

(a)

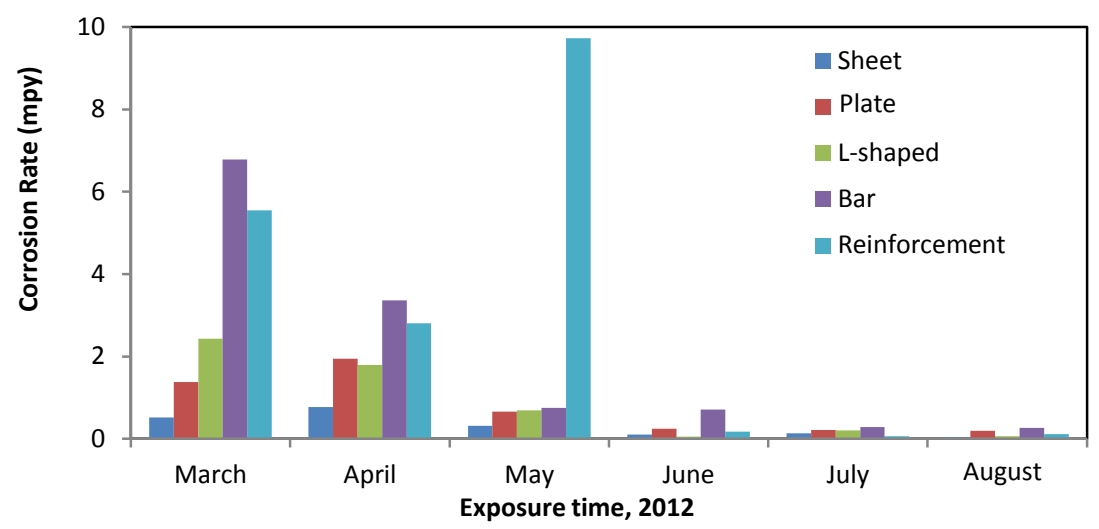

(b)

Figure 6. Corrosion rate from March to August 2012 at: (a) Lingke; (b) Lampulo.

The atmospheric corrosion rate of structural steels for Suak Ribee and Suak Pandan are given in Figure 7. The figure shows that the corrosion rate of Suak Ribee ranges from 0.265 to 3.957 mpy and that the corrosion rate of Suak Pandan ranges from 0.073 to $2.970 \mathrm{mpy}$. The results reveal that the corrosion rate profiles for each structural steel are similar for every month. This might be because of the relatively constant humidity and rainfall during March to August (Wahyunto et al., 2008).

Figure 8 shows the corrosion rate of structural steels that were exposed in Suak Seuke and Suak Geudebang. The corrosion rate for Suak Seuke is 0.090 to $4.101 \mathrm{mpy}$ and the corrosion rate for Suak Geudebang is 0.380 to $6.379 \mathrm{mpy}$. Here too, the corrosion rate for each form of structural steel has a similar profile for every month of exposure; again, possibly because the relative humidity and rainfall were constant during the exposure period (Wahyunto et al., 2008). Furthermore, Figures 7 and 8 also show that the highest corrosion rates among the structural steels are for the bar and reinforcing steel shapes. However, it is different for the samples from Banda Aceh and Aceh Besar; the corrosion rate profile for Aceh Barat is almost the same for each month from March to August, as previously indicated. 


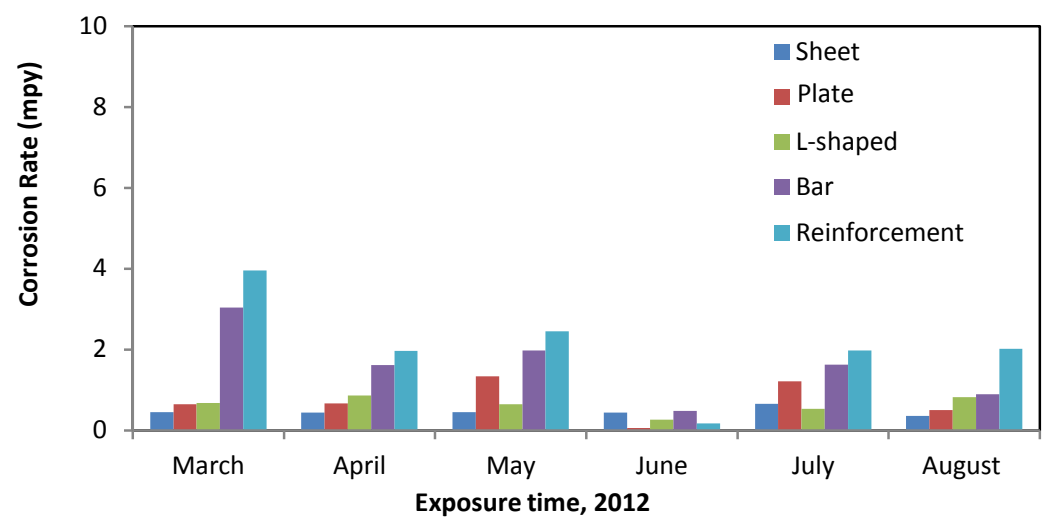

(a)

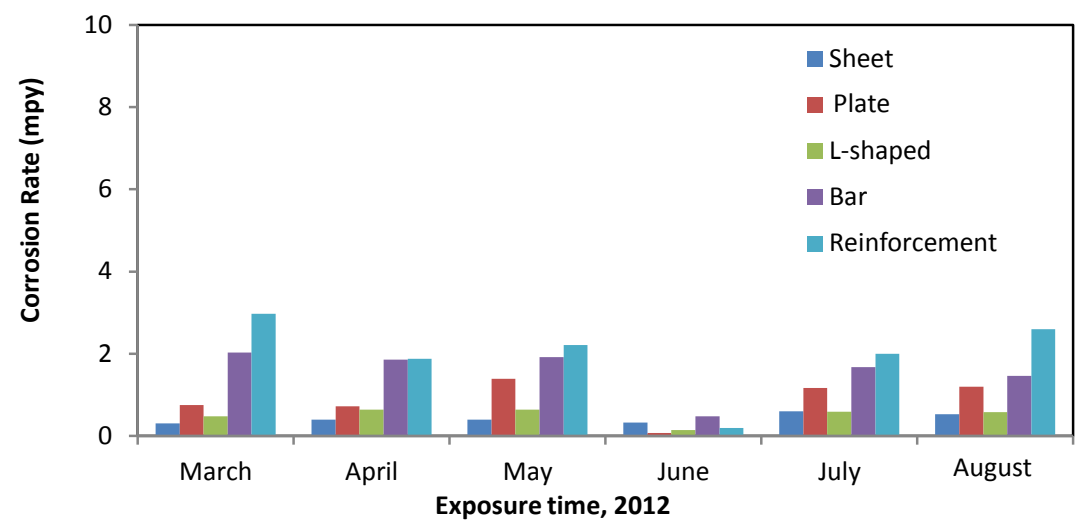

(b)

Figure 7. Corrosion rate from March to August 2012 at: (a) Suak Ribee; (b) Suak Pandan.

All these data indicate that the minimum level of relative corrosion resistance of exposed structural steels is good corrosion resistance and that the maximum is outstanding, according to the criteria in Table 2. Hence, these structural steels are safe for applications in the regions of exposure, i.e., the 2004 tsunami-affected area. Furthermore, the results reveal that the shape of structural steel affects its corrosion rate, i.e., the bar and reinforcing steel have the highest corrosion rate for all locations. The shape of structural steel might affect the atmospheric corrosion rate because each has experienced different manufacturing and treatment processes, which could change the corrosion-related properties of the material, such as polarization.

In addition, the results indicate that geographical factors might also influence the corrosion rate profile during the exposure time. The corrosion rate profiles for Aceh Barat from March to August are quite different to those for Banda Aceh and Aceh Besar. As previously mentioned, the corrosion rate profile of structural steel in Aceh Barat is relatively similar for every month, whereas during March to May, the corrosion rate in Banda Aceh and Aceh Besar is relatively higher than for the other months. Moreover, the corrosion rate profile for Banda Aceh and Aceh Besar are very similar because of their geographical proximity. 


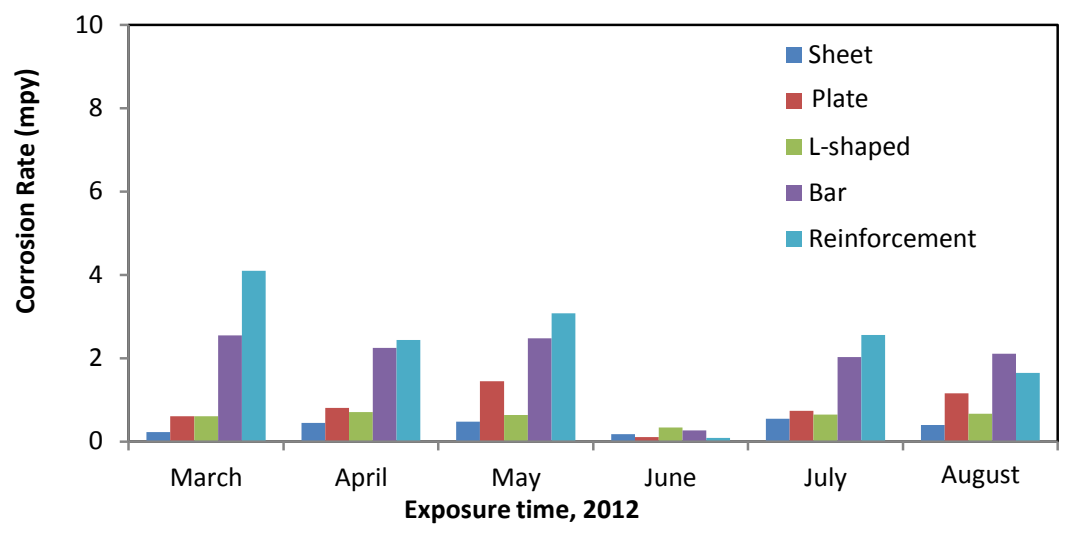

(a)

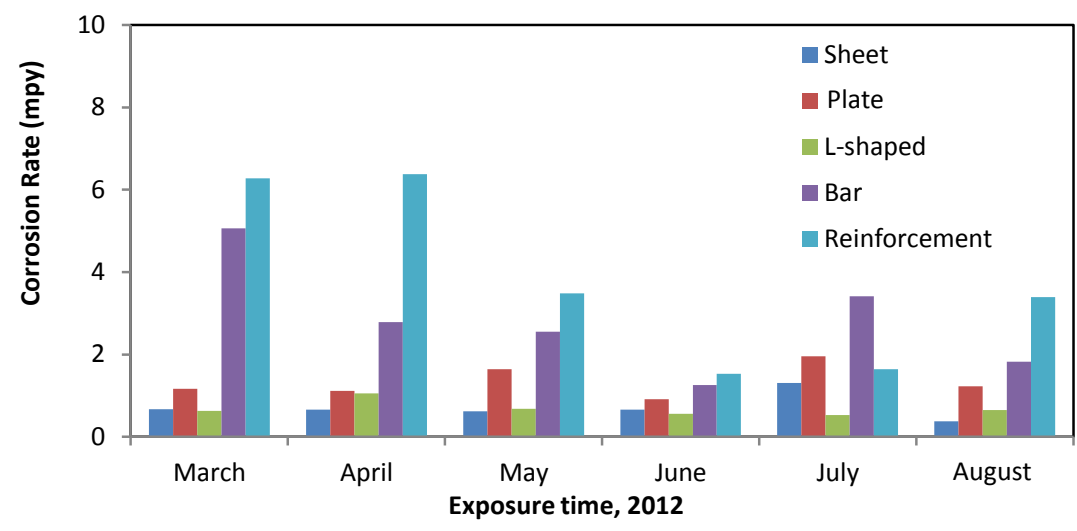

(b)

Figure 8. Corrosion rate from March to August 2012 at: (a) Suak Seuke; (b) Suak Geudebang.

\section{CONCLUSION}

Exposure tests to assess the rate of atmospheric corrosion on structural steels have been conducted in eight locations in the Aceh region, covering Banda Aceh, Aceh Besar, and the Aceh Barat Districts. The exposure tests were carried out according to the ASTM G50 standards. The specimens are carbon steel of five different shapes. The tests were carried over six months at all locations. The results show that the minimum and maximum relative corrosion resistance of the structural steels is good and outstanding, respectively. Hence, the structural steel can be utilized in the region with minimum risk from atmospheric corrosion. Furthermore, it appears that the shape of the structural steel might influence the atmospheric corrosion rate. This is possibly because each structural steel has undergone different manufacturing and treatment processes.

\section{ACKNOWLEDGMENTS}

This study was supported by the Ministry of Education and Culture of the Republic of Indonesia through the "Hibah Bersaing" Project Research grant no.: 033/UN11.2/LT/SP3/2012. 


\section{REFERENCES}

ASM International. 2003. ASM Handbook. Volume 13A. Corrosion: fundatmentals, testing, and protection. USA: ASM international.

BMKG. 2013. http://aceh.bps.go.id/index.php?r=artikel/view\&id=130 (Accessed 21 May 2013).

Fontana, M.G. 1987. Corrosion Engineering. $3^{\text {rd }}$ Edition. New York: McGraw-Hill.

Fuente, D. de la, Díaz, I., Simancas, J., Chico, B. and Morcillo, M. 2011. Long-term atmospheric corrosion of mild steel. Corrosion Science 53: 604-617.

Kuru, G. 2005. Penelitian FAO Mengenai Permintaan dan Penyediaan Kayu untuk Rekonstruksi pasca Tsunami di Indonesia. Consultant (in Indonesian).

Li, Y., Wei, Y., Hou, L. and Han, P. 2012. Atmospheric corrosion of AM60 Mg alloys in an industrial city environment. Corrosion Science 69: 67-76.

Ma, Y., Li, Y. and Wang, F. 2010. The atmospheric corrosion kinetics of low carbon steel in a tropical marine environment. Corrosion Science 52: 1796-1800

NACE. 2002. Cost of corrosion study unveiled, a supplement to material performance. NACE International, p. 2.

Ridha, M., Fonna, S., Huzni, S. and Ariffin, A. K. 2013. Corrosion risk assessment of public buildings affected by the 2004 Tsunami in Banda Aceh. Journal of Earthquake and Tsunami, 7(1): 1-22.

Roberge, P.R. 2008. Corrosion engineering: principles and practices. New York: McGraw-Hill.

Schweitzer, P.A. 2007. Fundamentals of metallic corrosion: atmospheric and media corrosion of metals. $2^{\text {nd }}$ Edition. New York: CRC Press.

Wahyunto Agus, F., Ritung, S. and Wahdini, W. 2008. http://balittanah. litbang.deptan.go.id/dokumentasi/buku/booklet\%20aceh\%20barat.pdf (Accessed 21 May 2013). 